\title{
PENGARUH PUPUK ORGANIK KULIT BUAH KOPI DAN PUPUK UREA TERHADAP PERTUMBUHAN DAN PRODUKSI NILAM (Pogostemon cablin)
}

\author{
Effect of Organic Fertilizer of Rind Coffee and Urea Fertilizer Composition on \\ Growth of Patchouli Plant (Pogostemon cablin) \\ M Irfan Yasir*, Any Kusumastuti, Made Same \\ Politeknik Negeri Lampung; Bandar Lampung, \\ e-mail:*irfanyasir1996@gmail.com, anyk@polinela.ac.id, madesame50@yahoo.co.id
}

\begin{abstract}
ABSTRAK
Penelitian dilaksanakan dikebun Pembibitan Jurusan Budidaya Tanaman Perkebunan dan Laboratorium Analisis Politeknik Negeri Lampung pada bulan Oktober 2018 sampai dengan Maret 2019. Penelitian menggunakan Rancangan Acak Kelompok (RAK) dengan pola faktorial $3 \times 3$. Faktor Faktor pertama adalah komposisi pupuk organik kulit buah kopi yang terdiri dari 3 taraf $\left(42,84\right.$, dan 168 g.polybag $\left.^{-1}\right)$. Faktor kedua adalah dosis pupuk urea (0, 1, dan 2 g.polybag1 ). Variabel pengamatan adalah tinggi tanaman, jumlah cabang utama, bobot basah tanaman, bobot kering tanaman dan rendemen. Hasil penelitian menunjukan bahwa tidak terdapat pengaruh pemberian, pupuk organik kulit buah kopi dan pemberian pupuk urea maupun interaksi keduanya. Rendemen tertinggi didapatkan pada perlakuan dosis pupuk 1 g.polybag-1 urea tertinggi yaitu $2.10 \%$
\end{abstract}

Kata kunci: kulit buah kopi, nilam, pupuk organik, pupuk urea, rendemen.

\section{ABSTRACT}

This study was conducted in the teaching farm and Analysis Laboratory of Politeknik Negeri Lampung in October 2018 until March 2019. The method used was a Randomized Block Design (RBD) with a $3 \times 3$ factorial pattern. The first factor was the composition of organic coffee beans which consists of 3 levels (42, 84, and 168 g.polybag-1). The second factor is the dose of urea fertilizer $(0,1$, and 2 g.polybag- 1$)$. Observation variables were plant height, number of main branches, plant wet weight, plant dry weight and yield. The results showed that there was no effect of organic fertilizer and the coffee fruit peel urea fertilizer and their interaction. The highest yield obtained at treatment dosages of 1 g.polybag-1 the highest urea 2:10\%.

Keywords: coffee fruit rind, patchouli, organic fertilizer, urea fertilizer, yield.

\section{PENDAHULUAN}

Indonesia merupakan penghasil minyak nilam terbesar didunia yang tiap tahun memasok sekitar 75\% kebutuhan dunia. Jumlah minyak atsiri tersebut, 60\% diproduksi di Nanggroe Aceh Darussalam dan sisanya berasal dari Sumatera Utara, Sumatera Barat, dan Jawa Tengah. Negara lain yang memproduksi minyak nilam adalah Brazil, Malaysia, India, dan Taiwan. Hampir seluruh produksi minyak nilam Indonesia diekspor terutama ke Amerika Serikat, negara Eropa Barat dan Jepang (Hildani, 2015). 
Upaya perbaikan teknik budidaya terutama dalam hal pemilihan bibit nilam, persiapan media tanam dan pemupukan untuk meningkatkan produksi nilam. Pemanfaatan pupuk organik dan pupuk hayati merupakan salah satu solusi memperbaiki kesuburan tanah dalam upaya memanfaatkan subsoil sebagai media tumbuh tanaman.

Erwiyono,dkk (2001) menjelaskan bahwa kompos organik yang diproduksi dari kulit buah kopi memiliki kandungan karbon $(\mathrm{C})$ dan nitrogen $(\mathrm{N})$ yang terus menyusut dari minggu pertama hingga minggu keenam dan dengan $\mathrm{C} / \mathrm{N}$ rasio yang relatif stabil pada periode yang sama.

Pupuk organik kulit buah kopi merupakan salah satu contoh pupuk organik. Pupuk organik kulit buah kopi memiliki kadar bahan organik dan unsur hara yang memungkinkan untuk memperbaiki sifat tanah. Hasil penelitian menunjukkan bahwa kadar C-organik kulit buah kopi adalah 4,53\%, kadar nitrogen 2,98 \%, fosfor 0,18\% dan kalium 2,26\%. Selain itu kulit buah kopi juga mengandung unsur $\mathrm{Ca}, \mathrm{Mg}, \mathrm{Mn}, \mathrm{Fe}, \mathrm{Cu}$ dan $\mathrm{Zn}$. Dalam 1 ha areal pertanaman kopi akan memproduksi limbah segar sekitar 1,8 ton setara dengan produksi limbah kering $630 \mathrm{~kg}$ (Dirjen Perkebunan, 2006).

\section{METODE PENELITIAN}

Penelitian ini telah dilakukan di kebun praktik Politeknik Negeri Lampung selama Bahan yang digunakan penelitian ini adalah bibit nilam, pupuk organik kulit buah kopi, pupuk Urea, pestisida, fungisida, polybag ukuran $20 \mathrm{~cm}$ x $30 \mathrm{~cm}$, air dan tanah. Alat yang digunakan dalam penelitian ini adalah cangkul, sekop, gembor, meteran, gunting, timbangan, sendok, penggaris, kamera dan alat tulis.

Metode penelitian menggunakan Rancangan Acak Kelompok Faktorial (RAK) berpola faktorial dengan 2 faktor dan 3 ulangan. Faktor pertama terdiri dari 3 taraf yaitu K1 : subsoil + 42 g.polybag ${ }^{-1}, \mathrm{~K} 2$ : subsoil +84 g.polybag ${ }^{-1}$ dan K3 : subsoil +168 g.polybag ${ }^{-1}$. Faktor kedua adalah dengan pemberian pupuk urea dengan 3 taraf ( $\mathrm{P} 0: 0 \mathrm{~kg} / \mathrm{ha}: 0$ g.polybag $\left.{ }^{-1}\right),(\mathrm{P} 1: 105$

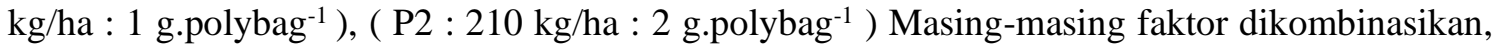
dengan demikian terdapat 9 kombinasi perlakuan sehingga penilitian ini terdapat 18 satuan percobaan. Setiap perlakuan ditanam 2 tanaman sehingga terdapat 36 tanaman

\section{Pelaksanaan Penelitian}

Persiapan lahan; areal yang akan digunakan untuk penelitian dibersihkan dari sampah dan gulma yang dapat menghambat laju pertumbuhan tanaman lalu permukaan tanah diratakan.

Persiapan Media; media tanam berupa tanah dan pupuk organik kulit buah kopi kemudian menyampurkan pupuk organik kulit buah kopi dan tanah sesuai perlakuan pada rancangan percobaan. Setelah itu masukan ke dalam polibeg lalu men empatkan polibeg sesuai dengan tata letak percobaan.

Persiapan Tanaman; dilakukan dengan penyeleksian bibit nilam yang berumur 1 bulan yang sehat.

Penanaman; dilakukan setelah bibit siap tanam dengan memindahkan bibit ke polibeg besar ukuran $20 \mathrm{~cm}$ x $30 \mathrm{~cm}$ berisi media yang telah dicampur pupuk organik kulit buah kopi sesuai perlakuan pada rancangan percobaan. 
Pemeliharaan; meliputi Penyiraman, penyulaman, penyiangan, perlindungan tanaman. Penyiraman dilakukan setiap pagi atau sore hari atau sesuai kondisi tanah. Penyulaman dilakukan untuk mengganti tanaman yang sudah mati atau layu agar jumlah tanaman sesuai target. Penyiangan gulma dilakukan secara manual dengan cara mencabut rumput-rumput yang tumbuh.

Panen dan pengeringan nilam; panen dilakukan pada pagi hari atau sore hari, pemanenan dilakukan dengan alat bantu gunting yang tajam. Sebelum daun nilam dikeringkan sebelumnya panenan daun-daun nilam dipotong-potong sepanjang 3-5 cm. Daun nilam yang akan diambil minyak atsirinya harus dikeringkan terlebih dahulu.

Proses pengeringan daun perlu dilakukan secepatnya, yakni sebelum daun tersebut mengalami perubahan warna. Pengeringan sebaiknya tidak dilakukan terlalu cepat, tetapi juga tidak terlalu lambat. Pengeringan daun nilam yang terlalu cepat dapat mengakibatkan daun menjadi rapuh dan sulit disuling. Sebaliknya bila pengeringan terlalu lambat, maka daun akan menjadi lembap dan timbul bau yang tidak disenangi akibat tumbuhnya jamur.

Proses pengeringan daun nilam sebaiknya dilakukan dengan benar, agar nantinya bisa dihasilkan minyak nilam bermutu baik. Pengeringan bertujuan menguapkan air yang terdapat dalam daun. Kadar air daun terbaik yaitu sekitar $15 \%$, tahap pengeringan daun nilam tersebut sebagai berikut : Daun nilam dikeringkan di kering anginkan dalam ruangan selama 5 sampai 7 hari atau dapat juga dengan menggunakan alat pengering buatan pada suhu $40-50{ }^{\circ} \mathrm{C}$ selama $4-5$ jam.

Penyulingan; penyulingan adalah salah satu cara untuk mendapatkan minyak atsiri, dengan cara mendidihkan bahan baku yang dimasukkan ke dalam ketel hingga terdapat uap yang diperlukan, atau dengan cara mengalirkan uap jenuh (saturated or superheated) dari ketel pendidih air ke dalam ketel penyulingan.

Variabel pengamatan; meliputi : analisis bahan pupuk organik kulit buah kopi, jumlah cabang, tinggi anaman, bobot kering tanaman, dan randemen nilam.

\section{HASIL DAN PEMBAHASAN}

\section{Analisis Subsoil dan Pupuk Organik Kulit Buah Kopi}

Berdasarkan hasil analisis media tanam yang dilakukan di laboratorium analisis Politeknik Negeri Lampung didapat bahwa media tanah subsoil dan pupuk organik kulit buah kopi seperti pada Tabel 1.

Tabel 1. Hasil analisis media subsoil dan pupuk organik kulit buah kopi

\begin{tabular}{lcccc}
\hline Parameter & Subsoil & Status & $\begin{array}{c}\text { pupuk organik } \\
\text { kulit buah kopi }\end{array}$ & Status \\
\hline $\mathrm{N}(\%)$ & 0.21 & Sedang & 3.94 & Sangat tinggi \\
$\mathrm{P}_{2} \mathrm{O}_{5}(\mathrm{ppm})$ & 2.61 & Rendah & 0.299 & Sangat rendah \\
$\mathrm{K}_{2} \mathrm{O}(\mathrm{ppm})$ & 1.20 & Rendah & 18.22 & Sangat rendah \\
$\mathrm{pH}$ & 4.26 & Masam & 7.07 & Netral \\
$\mathrm{C}(\%)$ & 1,36 & Rendah & 10.79 & Rendah \\
$\mathrm{C} / \mathrm{N}$ & 6,4 & Rendah & 2,7 & Sangat rendah \\
\hline
\end{tabular}

Sumber : Laboratorium Analisis Politeknik Negeri Lampung, 2019 
Berdasarkan hasil analisis yang tertera pada Tabel 1 menunjukan bahwa tanah awal yang digunakan dalam penelitian ini merupakan tanah yang miskin unsur hara dan memiliki tingkat kesuburan tanah yang rendah. Hal ini dapat dilihat dari hasil analisis $\mathrm{pH}$ tanah termasuk kriteria masam dan kandungan unsur $\mathrm{N}, \mathrm{P}$ dan $\mathrm{K}$ rendah sehingga tanah ini miskin secara fisik dan kimia. Dengan sifat yang demikian, tanah ini rendah akan bahan organik dan strukturnya tidak begitu baik sehingga peka terhadap erosi (Hardjowigeno, 1987). Oleh karena itu, diperlukan tindakan untuk membenahi tanah tersebut dengan cara memberikan kedalam tanah, salah satunya adalah dengan menambahkan pupuk organik kulit buah kopi kedalam tanah sebagai bahan pembenah tanah. Pupuk organik kulit buah kopi mengandung bahan organik dan unsur hara yang potensial untuk digunakan sebagai media tanam. Berdasarkan hasil analisis pada Tabel 1 menyatakan bahwa kandungan $\mathrm{N}$ pada pupuk organik kulit buah kopi sangat tinggi yaitu $3,94 \%$ sehingga dapat memenuhi kebutuhan $\mathrm{N}$ yang rendah pada tanah hal ini dikarenakan tanaman nilam membutuhkan unsur hara terutama nitrogen $(\mathrm{N})$ berperan penting sebagai pembentukan korofil tanaman. Menurut Ai dan Banyo (2011) menyatakan bahwa unsur hara nitrogen berguna sebagai pertumbuhan dan perkembangan tanaman sedangkan hasil analisis $\mathrm{P}$ pada Tabel 1 di atas menunjukan bahwa nilai kadungan $P$ sangat rendah yaitu 0,299\% sehingga tidak dapat meningkatkan kandungan $\mathrm{P}$ yang tersedia dalam tanah.

\section{Pengaruh Pupuk Organik Kulit Buah Kopi dan Pupuk Urea terhadap Tinggi Tanaman Nilam}

Berdasarkan Hasil sidik ragam diketahui bahwa perlakuan pupuk organik kulit buah kopi dan pupuk urea tidak berpengaruh nyata terhadap tinggi tanaman dan pada interaksinya tidak berpengaruh nyata pada tinggi tanaman umur 4 sampai 16 MST (Tabel 2).

Tabel 2. Pengaruh pupuk organik kulit buah kopi dan dosis pupuk urea terhadap tinggi tanaman

\begin{tabular}{lcccc}
\hline \multirow{2}{*}{ Perlakuan } & \multicolumn{4}{c}{ Waktu Pengamatan } \\
\cline { 2 - 5 } & 4 HST & 8 HST & 12 HST & 16 HST \\
\hline Subsoil+Pupuk organik buah Kulit Kopi & & & & \\
Subsoil+42 g.polybag $^{-1}$ & $26,33 \mathrm{a}$ & $29,93 \mathrm{a}$ & $30,92 \mathrm{a}$ & $32,19 \mathrm{a}$ \\
Subsoil+84 g.polybag $^{-1}$ & $31,89 \mathrm{a}$ & $34,81 \mathrm{a}$ & $38,81 \mathrm{a}$ & $40,93 \mathrm{a}$ \\
Subsoil+168 g.polybag $^{-1}$ & $29,00 \mathrm{a}$ & $31,64 \mathrm{a}$ & $34,93 \mathrm{a}$ & $36,78 \mathrm{a}$ \\
\hline Pupuk N $^{*}$ & & & \\
0 g.polybag & & & & \\
1 g.polybag- $^{-1}$ & $28,56 \mathrm{a}$ & $30,39 \mathrm{a}$ & $33,63 \mathrm{a}$ & $35,30 \mathrm{a}$ \\
2 g.polybag- & $29,96 \mathrm{a}$ & $30,06 \mathrm{a}$ & $33,81 \mathrm{a}$ & $36,00 \mathrm{a}$ \\
\hline Interaksi $^{-1}$ & $31,63 \mathrm{a}$ & $34,00 \mathrm{a}$ & $36,22 \mathrm{a}$ & $38,59 \mathrm{a}$ \\
\hline
\end{tabular}

Keterangan: Angka rata-rata yang diikuti oleh huruf yang sama menunjukkan tidak berbeda nyata berdasarkan uji BNT taraf 5\%.

ns* = tidak berbeda nyata

Tabel di atas menunjukan bahwa media tanam yang berasal dari pupuk organik kulit buah kopi, tidak berpengaruh nyata pada tinggi tanaman nilam hal ini diduga karena hasil analisis kandungan N, K, dan C-Organik kulit buah kopi sangat rendah serta pemberian dosis 
tidak mencukupi sehingga membuat tanaman tidak tumbuh secara maksimal tetapi pada perlakuan 84 gram.polybag ${ }^{-1}$ tinggi tanaman lebih baik dibandingankan perlakuan 42 g.polybag-

${ }^{1}$ hal ini diduga karena pemberian pupuk organik kulit buah kopi sesuai tidak dengan kebutuhan tanaman nilam. Hal ini sejalan dengan pernyataan Dwijoseputro (1996) yang menyatakan bahwa apabila unsur hara yang diberikan kurang dari kebutuhan yang optimal maka pertumbuhan tidak akan maksimal.

Sedangkan pada perlakuan 168 g.polybag ${ }^{-1}$ pupuk organik kulit buah kopi tidak lebih

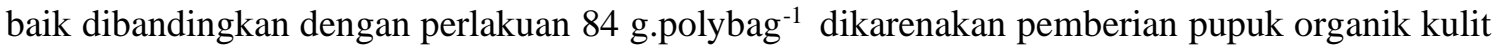
buah kopi berlebihan dapat mengakibatkan peningkatan kandungan unsur hara berlebih sehingga menjadi tidak efisien. Hal ini sesuai dengan penelitian Rizqiani, dkk. (2007) yang menyebutkan pemberian pupuk organik terhadap tanaman harus memiliki rekomendasi dosis dan frekuensi yang tepat dan tidak boleh berlebihan atau kekurangan.

Untuk perlakuan pemberian pupuk nitrogen terhadap tanaman nilam memberikan hasil yang tidak berbeda nyata hal ini diduga pemberian pupuk nitrogen tidak mencukupi kebutuhan tanaman nilam. Lingga (2005) menambahkan bahwa pupuk nitrogen berfungsi untuk memacu pertumbuhan pada fase vegetatif terutama daun dan batang.

\section{Pengaruh Pupuk Organik Kulit Buah Kopi dan Pupuk Urea terhadap Jumlah Cabang Tanaman Nilam}

Hasil sidik ragam menunjukan bahwa pemberian pupuk organik kulit buah kopi tidak berpengaruh nyata terhadap jumlah cabang tanaman nilam pada umur 4, 8, 12 dan 16 MST. Pemberian pupuk organik kulit buah kopi pada taman nilam berpengaruh nyata terhadap jumlah cabang pada tanaman nilam pada umur 4, 8, 12 dan 16 MST. Tidak terjadi interaksi antara pemberian pupuk organik kulit buah kopi dan pemberian pupuk $\mathrm{N}$ terhadap jumlah cabang tanaman nilam

Tabel 3. Pengaruh pupuk organik kulit buah kopi dan dosis pupuk urea terhadap jumlah cabang

\begin{tabular}{|c|c|c|c|c|}
\hline \multirow{2}{*}{ Perlakuan } & \multicolumn{4}{|c|}{ Waktu Pengamatan } \\
\hline & 4 MST & $8 \mathrm{MST}$ & $12 \mathrm{MST}$ & $16 \mathrm{MST}$ \\
\hline \multicolumn{5}{|c|}{ Subsoil + Pupuk organik kulit buah kopi } \\
\hline Subsoil + 42 g.polybag ${ }^{-1}$ & $3,00 \mathrm{a}$ & $4,78 \mathrm{a}$ & $5,85 \mathrm{a}$ & $7,93 \mathrm{a}$ \\
\hline Subsoil + 84 g.polybag ${ }^{-1}$ & $3,67 \mathrm{a}$ & $7,48 \mathrm{a}$ & $8,48 \mathrm{a}$ & $10,78 \mathrm{a}$ \\
\hline Subsoil + 168 g.polybag ${ }^{-1}$ & $3,41 \mathrm{a}$ & $7,15 \mathrm{a}$ & $8,63 \mathrm{a}$ & $9,11 \mathrm{a}$ \\
\hline \multicolumn{5}{|l|}{ Pupuk N } \\
\hline 0 g.polybag ${ }^{-1}$ & 3,33 a & 5,85 a & $7,52 \mathrm{a}$ & $9,52 \mathrm{a}$ \\
\hline 1 g.polybag ${ }^{-1}$ & $3,37 \mathrm{a}$ & $7,70 \mathrm{a}$ & $8,44 \mathrm{a}$ & $10,81 \mathrm{a}$ \\
\hline 2 g.polybag ${ }^{-1}$ & $3,37 \mathrm{a}$ & $5,85 \mathrm{a}$ & $7,00 \mathrm{a}$ & $7,48 \mathrm{a}$ \\
\hline Interaksi & ns & ns & ns & ns \\
\hline
\end{tabular}

Keterangan: Angka yang diikuti oleh huruf yang sama menunjukkan tidak berbeda nyata berdasarkan uji BNT taraf 5\%.

ns* = tidak berbeda nyata 
Tabel di atas menunjukan bahwa pemberian pupuk organik kulit kopi tidak berpengaruh terhadap jumlah cabang tanaman nilam pada umur 4,8,12 dan 16 MST. Hal ini diduga karena kandung $\mathrm{P}$ sangat rendah sehingga tidak dapat meningkatkan efisiensi kandungan $\mathrm{N}$ yang terdapat pada pupuk organik kulit buah kopi sehingga kemampuan $\mathrm{N}$ untuk memicu pertumbuhan cabang tidak optimal. Hal ini sejalan dengan pendapat Agustina (2004) menambahkan fosfor juga memiliki peran untuk meningkatkan efisiensi, fungsi dan penggunaan $\mathrm{N}$

Sedangkan pada perlakuan pemberian pupuk $\mathrm{N}$ menunjukan hasil yang tidak berbeda nyata hal ini karena penambahan dosis pupuk organik kulit buah kopi mengandung nitrogen yang sangat tinggi menyebabkan rusaknya vascular tanaman dalam hal ini xilem dan floem. Hal ini sejalan dengan penelitian Hernita, dkk. (2012) mengatakan pemberian pupuk nitrogen yang berlebihan pada dosis tinggi dapat menyebabkan keringnya bagian tanaman sehingga pertumbuhan tanaman terganggu.

\section{Pengaruh Pupuk Organik Kulit Buah Kopi dan Pupuk Urea terhadap Berat Kering Tanaman Nilam}

Hasil sidik ragam menunjukan bahwa kombinasi dosis pupuk nitrogen tidak memberikan pengaruh nyata terhadap berat basah pada tanaman nilam pada umur 4,8,12 dan 16 MST. Pemberian pupuk organik kulit buah kopi pada tanaman nilam dan interaksinya dengan pupuk $\mathrm{N}$ tidak memberikan pengaruh nyata pada tanaman nilam pada umur 4, 8, 12 dan 16 MST.

Tabel 4. Bobot kering tanaman nilam

\begin{tabular}{ccccc}
\hline $\begin{array}{c}\text { Pupuk urea } \\
(\text { g.polybag }\end{array}$ & \multicolumn{2}{c}{ Subsoil + Pupuk organik kulit buahkopi g.polybag ${ }^{-1}$ ) } & \multirow{2}{*}{ Rerata } \\
\cline { 2 - 3 } & 42 & 84 & 168 & \\
\hline 0 & $62,33 \mathrm{a}$ & $98,67 \mathrm{a}$ & $121,00 \mathrm{a}$ & $94,00 \mathrm{a}$ \\
1 & $91,67 \mathrm{a}$ & $152,33 \mathrm{a}$ & $145,00 \mathrm{a}$ & $129,67 \mathrm{a}$ \\
2 & $80,33 \mathrm{a}$ & $131,00 \mathrm{a}$ & $47,67 \mathrm{a}$ & $86,33 \mathrm{a}$ \\
\hline Rerata & $78,11 \mathrm{a}$ & $127,33 \mathrm{a}$ & $104,56 \mathrm{a}$ & \\
\hline
\end{tabular}

Keterangan: Angka rata-rata yang diikuti oleh huruf yang sama menunjukkan tidak berbeda nyata berdasarkan uji BNT taraf 5\%.

Berdasakan hasil analisis tabel diatas menunjukan bahwa bobot kering tanaman pada perlakuan 84 g.polybag ${ }^{-1}$ menunjukan hasil yang paling baik di antara perlakuan yang lain namun dari analisis sidik ragam ketiga perlakuan serta kombinasi pupuk organik kulit buah kopi dan pupuk urea tidak menunjukan perbedaan yang nyata dikarenakan pemberian pupuk organik kulit buah kopi harus sesuai dengan kebutuhan tanaman hal ini sesuai dengan penelitian Supriyadi (2014) bahwa bobot brangkasan kering yang optimal disebabkan tanaman memperoleh hara yang cukup sesuai dengan hara yang dibutuhkan sehingga fotosintesis dapat berjalan dengan baik sehingga menyebabkan peningkatan pada berat kering tanaman.

Pada data di atas terlihat bahwa bobot kering tanaman nilam yang di pupuk nitrogen dengan dosis urea 1 g.polybag ${ }^{-1}$ ternyata lebih berat dibandingkan dengan pemberian dosis 0 g.polybag ${ }^{-1}$ dan 2 g.polybag ${ }^{-1}$, hal ini dikarenakan pemberian pupuk nitrogen harus tepat dengan dosis yang cukup bagi tanaman terlihat data di atas apabila pemberian pupuk tidak mencukupi akan berpengaruh terhadap berat taman dan juga bila pemberian pupuk berlebihan juga tidak 
baik bagi perkembangan tanaman. Menurut Marsono (2005), menyatakan keuntungan menggunakan pupuk urea $(\mathrm{N})$ adalah mudah diserap tanaman. Selain itu kandungan urea $(\mathrm{N})$ sangat dibutuhkan pada awal pertumbuhan tanaman. Pendapat ini diperkuat pula oleh indrianti. (2017), menyatakan bahwa pemberian dan peningkatan dosis pupuk yang seimbang khususnya $\mathrm{N}, \mathrm{P}, \mathrm{K}, \mathrm{Ca}$ dan $\mathrm{Mg}$ dapat meningkatkan produktivitas tanaman nilam.

\section{Rendemen Tanaman nilam}

Kadar minyak atsiri nilam diperoleh dari hasil penyulingan daun nilam yang telah dikering anginkan hingga menjadi simplisia. Cara penyulingan yang digunakan dengan cara destilasi yang di lakukan di laboraturium politeknik negeri lampung. Kombinasi 1 g.polybag ${ }^{-1}$ pupuk $\mathrm{N}$ dan 84 g.polybag- ${ }^{-1}$ pupuk organik kulit buah kopi menghasilkan kadar nilam yang terbesar yaitu $17,4 \mathrm{ml}$.

Sedangkan pada kombinasi perlakuan pupuk organik kulit buah kopi 42 g.polybag ${ }^{-1}$ dan pupu urea 0 g.polybag ${ }^{-1}$ memiliki nilai kadar minyak terendah dibandingkan kombinasi perlakuan lainnya. Rendemen yang dihasilkan oleh kombinasi perlakuan pupuk urea 0 g.polybag $^{-1}$ dan pupuk organik kulit buah kopi adalah 15,8 ml.

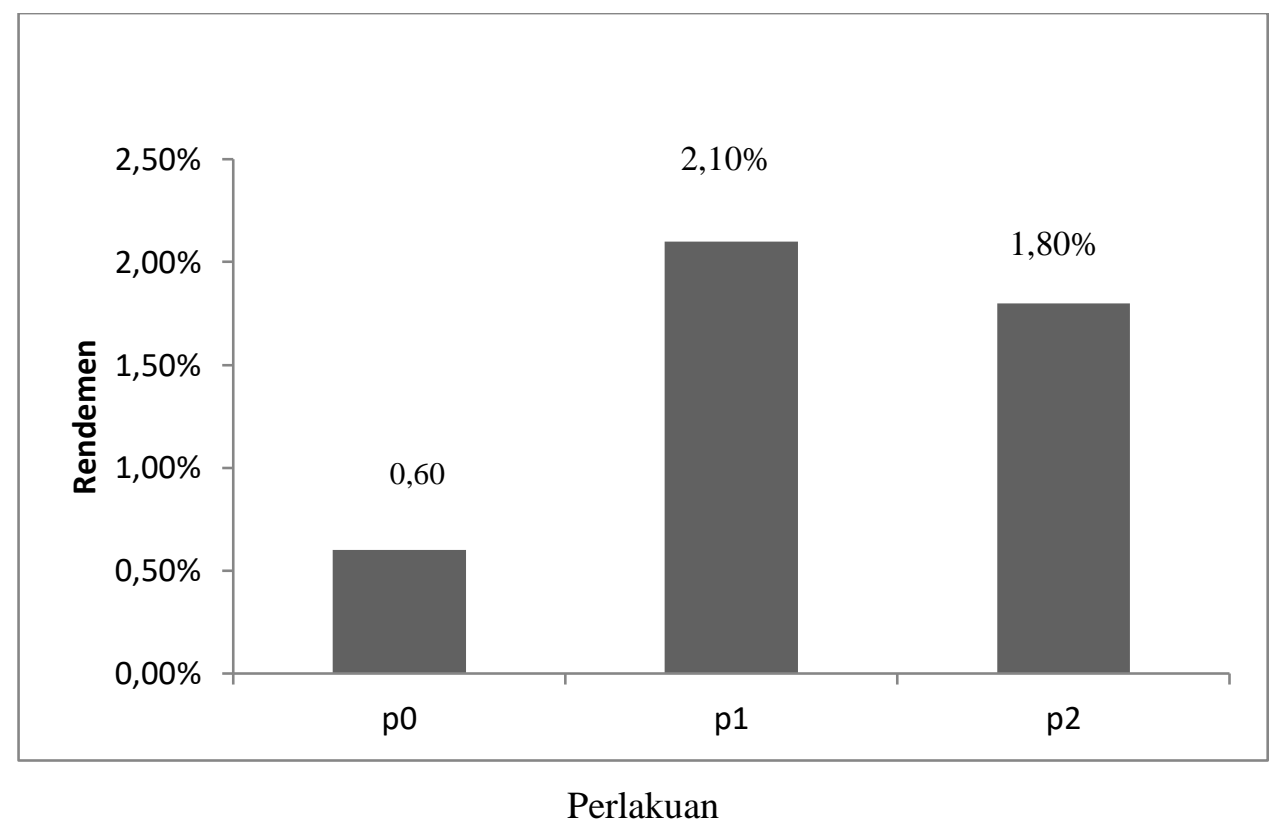

Gambar 2. Hasil Rendemen pada setiap perlakuan

$$
\begin{array}{ll}
\text { Keterangan : } & \mathrm{P} 0=0 \mathrm{~g}^{\text {g.polybag }}{ }^{-1} \text { urea } \\
& \mathrm{P} 1=1 \mathrm{~g}^{\text {g.polybag }}{ }^{-1} \text { urea } \\
& \mathrm{P} 2=2 \text { g.polybag }^{-1} \text { urea }
\end{array}
$$

Kadar minyak atsiri nilam diperoleh dari penyulingan daun nilam yang telah diikering anginkan . Minyak atsiri nilam diperoleh dengan cara penyulingan daun dan sedikit ranting nilam. Kadar minyak yang dihasilkan oleh tanaman pada perlakuan 1 g.polybag $^{-1}$ urea menghasilkan kadar minyak nilam dengan nilai tertinggi $(2.10 \%)$ hal ini diduga karena pada parameter pengamatan jumlah cabang penelitian ini, memiliki jumlah cabang yang banyak 
dibandingkan perlakuan lainnya sehingga memliki kadar minyak yang lebih tinggi juga dibandingkan perlakuan lainnya hal ini sejalan dengan penilitian Irfan (1989) semakin banyak proporsi tangkai, kadar minyak dan rendemen minyak semakin tinggi.

\section{KESIMPULAN}

Berdasarkan hasil penelitian diperoleh kesimpulan bahwa komposisi media subsoil dan pupuk organik kulit buah kopi tidak berpengaruh terhadap perumbuhan dan produksi tanaman nilam. Dosis pupuk urea tidak berpengaruh terhadap rendemen nilam pada seluruh kombinasi,. Tidak terdapat interaksi antara komposisi media subsoil dan pupuk organik kulit buah kopi serta pupuk urea terhadap pertumbuhan dan produksi tanaman nilam. Rendemen tertinggi didapatkan pada perlakuan pemberian dosis pupuk 1 g.polybag ${ }^{-1}$ dengan hasil rendemen urea tertinggi yaitu $2.10 \%$

\section{DAFTAR PUSTAKA}

Agustina, L. 2004. Dasar Nutrisi Tanaman. Rineka Cipta. Jakarta.

Ai dan Banyo, (2011) menyatakan bahwa unsur hara nitrogen berguna sebagai pertumbuhan dan perkembangan tanaman

Anggariningsih, S dan H.W. Utomo. 1981. Pengaruh Pemupukan Nitrogen dan Pospat Terhadap Sifat Fisik Tanah. Makalah Penunjang Pada Kongres Nasional Ke III HITI di Malang. Halaman 1-3.

Ayub dan Parnata. 2010. Meningkatkan Hasil Panen Dengan Pupuk Organik. Agromedia Pustaka. Jakarta

Baon, J.K., R. Sukasih dan Nurkholis, 2005. Laju Dekomposisi dan Kualitas Kompos Limbah Padat Kopi: Pengaruh Aktivator dan Bahan Baku Kompos. Pelita Perkebunan Vol. 21 No. 1.

Dirjen Perkebunan. 2006. Pemanfaatan Limbah Perkebunan. Dikutip dari http://ditjenbun.deptan.go.id/perbenpro/images/stories/Pdf/pedomanlimbahbukunop.pdf. Diakses pada tanggal 01 Februari 2012.

Dwijoseputro, D. 1996. Pengantar Fisiologi Tumbuhan. PT. Gramedia. Jakarta. 96 hlm.

Erwiyono., R. Nurkholis dan J.B. Baon. 2001. Laju Perombakan Kulit Buah Kopi, Jerami, Dan Cacahan Kayu Dengan Perlakuan Mikroorganisme Dan Kualitas Kompos Yang Dihasilkan. Pelita Perkebunan, 17, 64-71.

Etika dan Y.Vidha Vidha. 2007. Pengaruh Pemberian Kompos Kulit Kopi, Kotoran.

Hardjowigeno, S. 1987. Ilmu Tanah. Mediyatama Sarana Perkasa. Jakarta. Hlm : 288

Hasibuan, B.E. 2006. Pupuk dan Pemupukan. Usu-Press. Medan. Hal 74. Inceptisol. Skripsi. Jurusan Tanah Program Studi Ilmu Tanah Fakultas Pertanian Universitas Brawijaya.

Hernita, D., R. Poerwanto., A.D. Susila., dan S. Anwar. 2012. Penentuan Status Hara Nitrogen pada Bibit Duku. Jurnal Hortikultura 22(1): 29- 36 
Hildani, A., 2015. Penentuan Bilangan Asam dan Bobot Jenis Serta Kelarutan Dalam Etanol Dari Minyak Nilam (Pogostemon cablin Benth.). Fakultas Farmasi. Universitas Sumatera Utara. Medan.

Irfan. 1989. Pengaruh Lama Pengeringanginan dan Perbandingan Daun Dengan Batang Terhadap Mutu dan Rendemen Minyak Nilam. Skripsi Sarjana, Fakultas Teknologi Pertanian IPB, Bogor.

Leiwakabessy, P.M. 1977. Ilmu Kesuburan Tanah. Departemen Ilmu Tanah, Pertanian Bogor.

Lingga, P., 2005. Hidroponik, Bercocok Tanam Tanpa Tanah. Penebar Swadaya. Jakarta.

Marsono. 2005. Petunjuk Penggunaan Pupuk. Penebar Swadaya, Jakarta. 150 hlm.

Martin, A. B., Same, M., \& Indrawati, W. (2015). Pengaruh media pembibitan pada pertumbuhan setek lada (Piper nigrum L.). Jurnal Agro Industri Perkebunan, 3(2), 94107.

Mulia, A. 2010. Respons Tanaman Sawi terhadap Pupuk Kulit Kopi pada Lahan Kering Ultisol.www.Purplsounsri.org/dokumen/9_irianto\&andri \%20pardosi-revisil. Diakses pada tanggal 23 November 2015.

Muryanto, U. Nuschati, D. Pramono dan T. Prasetyo. 2004. Potensi Limbah Kulit Kopi Sebagai Pakan Ayam. Lokakarya Nasional Inovasi Teknologi Dalam Mendukung Usaha ternak Unggas Berdayasaing. Balai Pengkajian Teknologi Pertanian Jawa Tengah.

Nio. S dan Y. Banyo. 2011. Konsentrasi Klorofil Daun sebagai Indikator Kekurangan Air pada Tanaman. Junal Ilmiah Sains. Vol. 11, No. 2. Manado: Program Studi Biologi FMIPA Universitas Sam Ratulangi.

Nuryani, Y. 2006. Budidaya Tanaman Nilam (Pogostemon cablin Benth.). Balai Penelitian Tanaman Rempah dan Aromatik.

Pandey, A. C.R. Soccol P, Nigam D. Brand, R. Mohan dan S. Roussos. 2000. Biochemical Engineering Journal, 6, 153-162.

Prayugo, S. 2007. Media Tanam untuk Tanaman Hias. Penebar Swadaya. Jakarta.

Rizqiani, N. F., E. Ambarwati dan, N. W. Yuwono. 2007. Pengaruh Dosis dan Frekuensi Pemberian Pupuk Organik Cair Terhadap Pertumbuhan dan Hasil Buncis (Phaseolus vulgaris L.) Dataran Rendah. Jurnal Ilmu Tanah dan Lingkungan 7 (1): 43-53.

Siregar, H.M. 2000. Upaya meningkatkan produktivitas pada budidaya tempuyung (Sonchus arvensis L.). Gakuryoku 6 (2): 92-95.

Sitio, Y., Wijana, G., \& Raka, I. G. N. (2015). Pemanfaatan Tandan Kosong Kelapa Sawit dan Pupuk Nitrogen Sebagai Substitusi Top Soil terhadap Pertumbuhan Bibit Kelapa Sawit (Elaeis guineensis Jacq.) PeriodePre Nursery. E-Jurnal Agroekoteknologi Tropika (Journal of Tropical Agroecotechnology).

Supriyadi. 2014. Pengaruh Penggunaan Sludge Pome dan Batuan Fosfat Alam Terhadap Pertumbuhan Bibit Kakao (Theobroma cacao L). Skripsi Diploma 4. Politeknik Negeri Lampung. Bandar Lampung.

Sutejo, M.M. 2002. Pupuk dan Cara Pemupukan. PT Asdi Mahasatya, Jakarta. 
Agritrop, Vol. 18 (1): 78 - 87

Wibowo R. (2010). Pemanfaatan Limbah Kulit Buah Kopi Sebagai Media Tanam Alternatif Untuk Pertumbuhan Tanaman Anthurium (Anthurium plowmanii Scoat). Skripsi. Jurusan Budidaya Pertanian, Fakultas Pertanian, Universitas Brawijaya

Widya.P.I. 2017. Pengaruh Jenis dan Dosis Penggunaan Pupuk Kandang Terhadap Produksi Segar Jumlah Anakan Proporsi. Skripsi. Jurusan peternakan. Fakultas Pertanian. Universitas Lampung

Wuryaningsih, S. dan S. Andyantoro. 1998. Pertumbuhan Stek Melati Berbukusatu Dan Dua Pada Beberapa Macam Media. Agri Journal. 5 (1-2) : 32-41. 